\title{
ERRATUM
}

\section{The radical SAM enzyme AlbA catalyzes thioether bond formation in subtilosin $A$}

Leif Flühe, Thomas A Knappe, Michael J Gattner, Antje Schäfer, Olaf Burghaus, Uwe Linne \& Mohamed A Marahiel

Nat. Chem. Biol. 8, 350-357 (2012); published online 26 February 2012; corrected after print 16 April 2012

In the version of this article initially published, $S$-adenosyl methionine was drawn with a radical instead of a cation in Figure 4 . The error has been corrected in the HTML and PDF versions of the article.

\section{CORRIGENDUM}

\section{A selective inhibitor reveals $\mathrm{PI} K \mathrm{~K} \gamma$ dependence of $\mathrm{T}_{H} 17$ cell differentiation}

Giovanna Bergamini, Kathryn Bell, Satoko Shimamura, Thilo Werner, Andrew Cansfield, Katrin Müller, Jessica Perrin, Christina Rau, Katie Ellard, Carsten Hopf, Carola Doce, Daniel Leggate, Raffaella Mangano, Toby Mathieson, Alison O'Mahony, Ivan Plavec, Faiza Rharbaoui, Friedrich Reinhard, Mikhail M Savitski, Nigel Ramsden, Emilio Hirsch, Gerard Drewes, Oliver Rausch, Marcus Bantscheff \& Gitte Neubauer

Nat. Chem. Biol. 8, 576-582 (2012); published online 29 April 2012; corrected after print 16 May 2012

In the version of this article initially published, the name M. Sunose was misspelled in the Acknowledgements. The error has been corrected in the HTML and PDF versions of the article.

\section{CORRIGENDUM}

\section{Lysophosphatidic acid directly activates TRPV1 through a C-terminal binding site}

Andrés Nieto-Posadas, Giovanni Picazo-Juárez, Itzel Llorente, Andrés Jara-Oseguera, Sara Morales-Lázaro,

Diana Escalante-Alcalde, León D Islas \& Tamara Rosenbaum

Nat. Chem. Biol. 8, 78-85 (2012); published online 20 November 2011; corrected after print 15 June 2012

In the version of this article initially published, the amount of LPA used in behavioral assays was incorrectly stated in the Methods section as $3 \mu \mathrm{g}$ when it should have read $4.1 \mu \mathrm{g}$. Also, the details of preparation of LPA stock solutions were incomplete in the Methods section. The errors have been corrected in the HTML and PDF versions of the article.

\section{CORRIGENDUM}

\section{A biosensor generated via high-throughput screening quantifies cell edge Src dynamics}

Akash Gulyani, Eric Vitriol, Richard Allen, Jianrong Wu, Dmitriy Gremyachinskiy, Steven Lewis, Brian Dewar, Lee M Graves, Brian K Kay, Brian Kuhlman, Tim Elston \& Klaus M Hahn

Nat. Chem. Biol. 7, 437-444 (2011); published online 12 June 2011; corrected after print 15 June 2012

In the version of this article initially published, the residue numbers indicated in the $y$-axis labels in Figure $3 c$ were incorrectly written as 24, 53, 55 and 53 from the origin but should have read 24, 52, 53 and 55. The error has been corrected the PDF and HTML versions of this article.

\section{ERRATUM}

\section{Research Highlights}

Nat. Chem. Biol. 8, 320 (2012); published online 16 March 2012; corrected after print 20 June 2012

In the version of this article initially published, the doi for the article referred to in the highlight entitled "O-GlcNAc in the dark" is incorrect. The correct doi is 10.1101/gad.182378.111. The error has been corrected in the HTML and PDF versions of the article. 